\title{
Galen and his treatise on grief
}

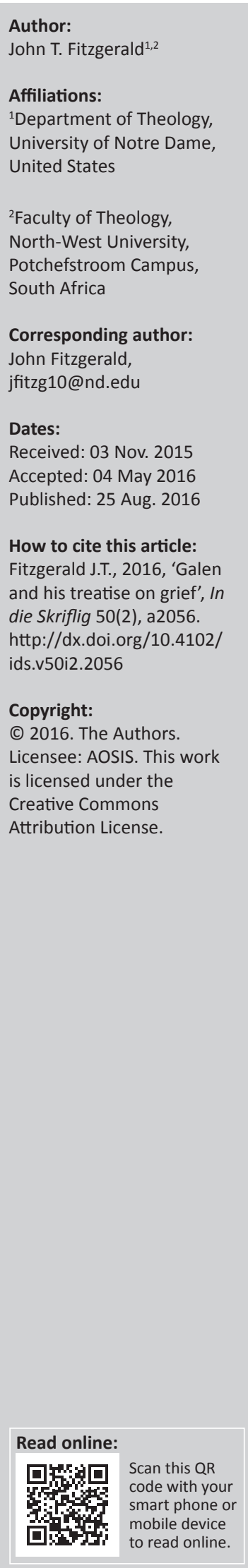

Throughout his career, Fika Janse van Rensburg has rightly insisted on the importance of the socio-historical context in interpreting early Christian literature. Although New Testament scholars have given careful attention to many aspects of this context, they have generally neglected writings by physicians. This neglect includes the numerous works of the philosopherphysician Galen (129-ca. 216 or 217 CE), who was one of the Roman Empire's most prolific writers. As a corrective, this article focuses on Galen, with attention given to his life and to a recently discovered treatise on distress or grief $($ lype $)$, known as De indolentia [Avoiding Distress or On Freedom from Distress]. Galen discusses grief from both a physiological and philosophical perspective, and his treatment of this emotion and common human experience provides an important context for the statements about lype found in the New Testament and other early Christian documents.

\section{Introduction}

In his work as a New Testament scholar, Fika Janse van Rensburg has rightly insisted on exegetes taking seriously the socio-historical context in which the early Christians produced the documents that now comprise the New Testament canon. This context is not mere stage décor - such a dispensable piece of furniture in a typical play - but a key component of the text's historical meaning (Janse van Rensburg 2000). When interpreters treat the 'backgrounds' of the New Testament as a hermeneutically insignificant 'backdrop' to the text, they sharply devalue its context by viewing it as 'at most providing a setting for the action that takes place in front, on the stage, without actually being part of the action' (Malherbe 2014:3). Such a procedure increases the risk of eisegesis, that is, the possibility of reading one's own ideas into the text rather than deriving an ancient author's ideas from the text.

The New Testament was written and read by Christians living in a world that was fundamentally different from the modern world. That very fact means that we, as 21st century interpreters, must constantly be on guard against importing our own assumptions and ideas into the ancient text. One of the best safeguards against this possibility is to take seriously the various contexts of early Christianity such as the cultural, economic, historical, linguistic, medical, political, religious, social and other aspects of the Roman Empire in which the Jesus-movement came into existence and developed. That task entails reading widely in the documents deriving from the ancient Mediterranean world, so that 'we learn to see with the eyes and hear with the ears of the ancients: their scale of values, their questions, their hopes and fears, joy and work' (Van Unnik 1971:210). Early Christians were not hermetically sealed off from their non-Christian Jewish and Gentile neighbours, for both shared the same environment, the same cultural, intellectual, linguistic and social ecological system as it were (Malherbe 2014:3-5). By learning to read ancient texts with 1st century eyes and ears, we strive 'to get within the horizon of understanding of Jews and Gentiles within the early Christian period' so as 'to do justice to the semantic nuances of the words and phrases that meet us on the pages of the New Testament' (Van der Horst 2007:1003).

One of the most neglected aspects of the Greco-Roman context of early Christianity is its medical context. By making such a claim I do not mean to imply that the medical terminology found in the New Testament has been neglected. It has indeed received attention, not only in the debate whether the author of Luke-Acts was a physician (Cadbury 1919:39-64; 1926; Hobart 1882), but also in other documents such as the Pastoral Epistles, whose author used medical imagery in a skilful manner, but was not himself a physician (Malherbe 1980). I mean rather that biblical scholars have not given as much attention to the corpus of ancient medical works as they have devoted to historical, literary, and philosophical works. The same judgement applies to nonmedical works written by people who were physicians. This is especially true of Galen, who, to be sure, has received occasional treatment (Alexander 1995; 2008; Grant 1983; Mansfeld 2004; Wilken 1984:68-93), but not as much as might have been expected of an author whose 'writings in Greek 
amount to approximately $10 \%$ of all surviving Greek literature before AD 350' (Nutton 2004:391, n. 21).

In this article, the focus will therefore be on Galen and especially on a recently discovered work of his that deals with lype , a Greek word that indicates the kind of emotional turmoil implied by the English terms anxiety, distress, grief, and pain (Fitzgerald 2014:207-208). As one of the primary emotions or passions, lype and the other emotions (such as anger) received extensive treatment both individually and collectively by ancient philosophers and moralists (Fitzgerald 2008:9-12). As might be expected, the New Testament also reflects a keen awareness of lype as a common human experience, with lype and/or its cognates (alypos, lypeō, perilypos, syllypeō) appearing in all four gospels, in five of the letters in the Pauline corpus (Romans, Ephesians, Philippians, 1 Thessalonians, and especially 2 Corinthians), in Hebrews and in 1 Peter (1:6; 2:19), a document that has been the main focus of Janse van Rensburg's recent scholarship on the New Testament (2004; 2005; 2006; 2009; 2011). Given the importance of lype in human experience in general, and in the New Testament in particular, it has naturally attracted ongoing scholarly attention (Bultmann 1967; Nasrallah 2012; Schmidt 1878:574-595; Spicq 1994; Welborn 2011), but the relevance of Galen and his treatment of lype is only beginning to be brought to bear on early Christian literature (Thompson 2015; White 2014; Wright 2014).

The following discussion has four main parts. In the first part an introduction to Galen's life will be provided, because his biography is generally unfamiliar to many biblical scholars and most theologians. In the second part the discovery of his work on the avoidance of lype (De indolentia) and the place of this treatise within the corpus of Galen's works will be discussed. In the third part an overview of the content and concerns of De indolentia will be provided, and in the fourth part Galen's understanding of lype will briefly be compared and contrasted with that of some New Testament authors on three topics. The article ends with a brief conclusion.

\section{Galen as philosopher and physician: An overview of his life}

Galen was born in 129 CE to wealthy parents in Pergamum, ${ }^{1}$ which boasted an acclaimed library and a famous Asclepieion. This sanctuary was exceptionally large and had a precinct that contained a library that was undoubtedly used by Galen when he lived in Pergamum. Later in life he was particularly dedicated to Asclepius, professing himself the god's devotee (therapeutess) after the god saved him from an abscess-induced condition that otherwise would have proved fatal (De libris propriis [On My Own Books] 2.8). ${ }^{2}$

1.Details of Galen's life are sketchy, compounded by the problem that Galen provides contradictory biographical information at key points. The synopsis of Galen's life given in the text is intended to be approximate, not exact, and it is based mainly on Nutton (1973, 2004:216-229) and Boudon-Millot (2007:vii-xc).

2.Galen's references to Asclepius are conveniently assembled by Edelstein and Edelstein (1945) and include testimonies $144,229-230,245,338,372,401,413$ Edelo 436, 458-459, 473, 595, 620 and 803 . For Pseudo-Galen, see testimonies 221, 35 and 381 . The 405 . 436,620 and 803 . For additional references to thecult at Pergamum, see testimonies 433-437 (oracles) and 569-571 (festivals and games). For Galen's Asclepius-piety, see Kudlien (1981).
Galen began the study of philosophy in his native city at the age of 14 (143 CE), attending lectures by a Stoic, a Platonist, a Peripatetic and an Epicurean. His father, Nicon, accompanied him to these lectures and counselled his son not to identify himself with any philosophical school. Galen heeded that advice his entire life, espousing philosophical pluralism and evaluating the tenets of all schools by the criterion of demonstrated proof (De propriorum animi cuiuslibet affectuum dignotione et curatione [On the Diagnosis and Treatment of the Emotions] 8). When he was 16 or 17 (145 or $146 \mathrm{CE}$ ), Galen began the study of medicine, doing so on the basis of instructions that Asclepius had given to his father in 'clear dreams'. ${ }^{3}$ In assessing this new course of study, it is important to recall that the medical profession in antiquity did not have the social cachet that it often has in modern times. Because the ancient practice of medicine was often associated with manual labour and involved payment for services rendered, it was not a typical profession for the social elite (Kleijwegt 1991:135-155). But the strong belief of both father and son in dreams as a means of divine revelation was decisive and so, from that point on, Galen studied medicine and philosophy simultaneously (De ordine librorum suorum [The Order of My Own Books] 4.4). Both subjects continued to be of prime importance to him throughout his life, partly because he saw them as intertwined pursuits. He was the quintessential iatrophilosophos ${ }^{4}$ [physician-philosopher] and the title of one of his later works, The Best Doctor Is Also a Philosopher (Quod optimus medicus sit quoque philosophus), reflects his view about the intrinsic inseparability of the two disciplines, which simultaneously functioned to enhance the intellectual respectability of his work as a physician (Bowersock 1969:66-68; Kleijwegt 1991:136-143).

The death of Galen's father's some three years later (148 or 149 CE) provided the catalyst for him to leave Pergamum and go to Smyrna to continue the study of medicine, also taking advantage of the Platonist philosopher Albinus's presence in the city to hear his lectures in approximately 151 or 152 (De ordine librorum suorum 2.1). Next, he left Smyrna for Corinth, planning to study there with the anatomist Numisianus, but he left there soon after discovering that the latter was no longer in Corinth, or, alternatively, had died shortly before Galen's arrival. He, then, moved to Alexandria where he spent several years and completed his formal medical education (Von Staden 2004).

Galen was atypical in regard to the age at which he began to study medicine, the places where he pursued his studies and the duration of those studies. Kleijwegt (1991:155-165) argues that the typical age at which one began medical studies was 14 (the age when Galen started to study philosophy) and that medical training usually lasted three to four years, so that most beginning physicians were 17 or 18 when they began to work independently. By contrast, Galen began his medical studies when he was 16 or 17 and spent some $11-12$ years

3.Galen, De ordine librorum suorum [The Order of My Own Books] 4; De methodo medendi [On the Method of Medicine] 9.609.

4.The Greek term occurs on an inscription given by Baillet (1920-1926:1298). 
pursuing those studies, which is far more time spent studying than any other known ancient physician. Moreover, most doctors who learned their craft at one of the great medical centres of antiquity (as opposed to those whose training was 'on the job' as apprentices) studied in only one geographical locale. Galen, by contrast, studied in three different places (Pergamum, Smyrna and Alexandria) and attempted to study in a fourth (Corinth). Without doubt, these are some of the factors that contributed to his subsequent professional success.

In early $157 \mathrm{CE}$ he returned to his native Pergamum, where he served as a physician for a troupe of gladiators until 161. Next, he went to Rome for the first time (162-166 or 167), where he won acclaim for his medical demonstrations and was championed by the former suffect consul Flavius Boethus, who became one of Galen's patrons. ${ }^{5}$ He returned to Pergamum in 167 for what turned out to be a very short stay, for he left soon thereafter on a trip to collect herbs and minerals for his pharmacological work as a physician. He travelled to Syria-Palestine, where Flavius Boethus was now the consular legate, ${ }^{6}$ visiting Caesarea Maritima, Jericho and the Dead Sea, and then going to Cyprus before returning to Asia Minor.7

Summoned in $168 \mathrm{CE}$ to Aquileia in northern Italy by the emperors Marcus Aurelius and Lucius Verus, he subsequently (169) became a court physician in Rome, which was to be his chief residence for the remainder of his life, though he did return to Pergamum for a time during the 190s. It was in Rome that he produced the bulk of his writings, including De indolentia, which was written in 193. He died at some point after 204, with an Arabic tradition placing his death in 216 or 217.

\section{The discovery of De indolentia and its place within the corpus of Galen's works}

Galen's De indolentia is one of 27 complete treatises of Galen and Pseudo-Galen that are preserved in a 15th century codex known as Vlatadon 14, with its name indicating that it is housed in the Vlatades monastery in Thessaloniki, Greece. Unfortunately its true identity had gone unrecognised, because it was preserved under two corrupted titles. It was only in January 2005 that the true contents of the work were discovered (Boudon-Millot 2008a; 2008b). Since then it has sparked the interest of scholars from a wide array of disciplines.

In all likelihood De indolentia is identical to a work that he calls peri alypias [On the Avoidance of Distress or Freedom from

\footnotetext{
5.On Flavius Boethus as Galen's patron, see especially Johnson (2010:78-80, 85-86). Boethus was particularly interested in anatomy and observed some of Galen's dissections and Galen produced nine works (collectively containing 43 books) in response to Boethus' requests.
}

6. Boethus was a native of Ptolemais. His appointment as legate, made during Galen's first stay in Rome, thus meant a return to the area where he was born and with which he was presumably well-acquainted. He served there in approximately 166168 , dying in office. On Boethus as legate, see Smallwood (1976:479, 552). Undoubtedly, one of Galen's reasons for undertaking the trip to Syria-Palestine was to visit his patron.

7.On this trip, see Walsh (1927). Nutton (1973:165-169) calls attention to Galen's travels and emphasises that physicians were frequently itinerants in the GrecoRoman world (see e.g. Seneca, Epistulae morales [Moral Epistles] 104.19).
Distress] in his De libris propriis 15.1. ${ }^{8}$ The latter, known in English as On My Own Books, is a bibliographical treatise that he wrote towards the end of his life. ${ }^{9}$ Here he divides his literary corpus into a number of categories, which usually appear as headings in the text. Some of these categories are temporal, ${ }^{10}$ but the vast majority are topical. These subjects, which begin with his medical writings, are as follows: writings dealing with anatomy (De libris propriis 4 ) and the function and usefulness of various parts of the body observed during dissection (5); works on the therapeutic method (6) and therapeutics (7), that is, healing; treatises on prognosis, that is, on the progression of diseases and the best times for physicians to intervene or not intervene (8); commentaries on Hippocrates (9); works dealing with Erasistratus (10) ${ }^{11}$; works dealing with Asclepiades $(11)^{12}$; controversies with the Empiricists (12) and the Methodists (13). Then follow works belonging to other subjects: logic and logical proofs ('demonstrations') (14); books dealing with moral philosophy (15); works on the philosophies of Plato (16), Aristotle (17), the Stoics (18), and the Epicureans (19); and, finally, works on linguistics and rhetoric (20).

Of these various categories, the one devoted to moral philosophy (peri tôn tềs êthikês philosophias) is the category to which Galen assigns De indolentia and 24 other works. The importance of recovering this work is underscored by the fact that, of the two dozen other works belonging to the category of moral philosophy, only one other (On the Diagnosis and Treatment of the Emotions and Errors) is extant in Greek, ${ }^{13}$ and only one more (De moribus [Moral Character]) exists in an Arabic summary. ${ }^{14}$ Consequently, to have recovered a Greek

8.On the translation of the work's title, see Fitzgerald (2014:207-208). Of course, given the enormous number of books that Galen produced - there are more than 170 extant treatises that bear his name, with almost 140 of them generally regarded as genuine (Von Staden 2004:179) - and the fact that he does not include every work in his catalogue of books in De libris propriis, it is certainly possible that he wrote more than one work on this subject and that the work preserved in Vlatadon 14 is not the book mentioned in De libris propriis. But there are no Vlatadon 14 is not the book mentere title (peri alypias) to refer to De indolentia. Other scholars, however, prefer the title peri alypēsias as the most likely original reading of the manuscript.

9.The work is contained in only one Greek manuscript, which is lacunose, but important supplements from an Arabic translation of the work have recently come to light. These supplements permit editors to restore the titles of three works missing from the Greek manuscript (see esp. Boudon [Boudon-Millot] 2002), who translates the Arabic material. The latter also includes a new section to the work in which the translator enumerated books written by Galen, but not mentioned by him. The translation of On My Own Books by Singer (1997:3-22) was done before the Arabic material was available and does not include it. This affects the citation of the work. Whereas the Greek manuscript has 17 chapters, the new edition of Boudon-Millot (2007) has 20 chapters. Consequently, De indolentia is mentioned in 12.1 of Singer's translation, but in $\mathbf{1 5 . 1}$ of the new edition. The latter is used here.

10.The temporal categories occur at the beginning of the work: works written during Galen's first stay in Rome (De libris propriis 1); books written earlier in Pergamum and Smyrna (2); and books completed and revised after his summons to Aquileia (3).

11.On Erasistratus of Ceos (ca. 315-240 BCE), see Von Staden (1997) and Nutton (2004:133-137).

12.On Asclepiades of Bithynia (1st or 2nd century BCE), see Vallance (1990) and Nutton (2004:167-170)

13.In the manuscript tradition, this treatise has been treated as two distinct works and transmitted separately (see Boudon-Millot 2007:225, n. 10). Consequently, the two books that comprise this treatise are sometimes treated as two separate works and given different abbreviations. Hankinson (2008), for example, uses the abbreviation Aff.Dig. to refer to the diagnosis and treatment of the soul's passions (De propriorum animi. to ruslibet affectuum dignotione et curatione) and the asions (De propriorum animi cuiluslibet affectuum dignotione et curatione), and the abbreviation Pecc.Dig. to refer to the diagnosis and cure of the soul's errors (De animi cuiuslibe peccatorum dignotione et curatione). In most modern editions and translations, one work (see e.g. Marquardt, Von Müller \& Heimrich 1884; Harkins 1963).

14.For an English rendering of the Arabic summary of De moribus, see Mattock (1972). 
copy of one of his previously lost works of ethical philosophy is of great importance to anyone concerned with the moral discourse of the Greco-Roman world.

\section{An overview of De indolentia}

Galen's treatise is a response to a letter (1) written to him by an old acquaintance, someone who, he says, was 'reared and educated with us from the beginning' (51; see also 57: 'educated with $\mathrm{me}^{\prime}$ ), a phrase that implies an association extending all the way back to Pergamum, Galen's native city. ${ }^{15}$ Galen never identifies this individual, but he mentions that this associate often heard Galen give speeches (39); that he was present with Galen in Rome when a plague broke out on a previous occasion (1); that he apparently was already in possession of some of Galen's works or had easy access to them (67); and that he had heard about Galen's later misfortunes (1). In short, the correspondent is an old boyhood acquaintance with whom Galen has remained in touch for a long time. The particular misfortune that has occasioned this individual's letter to Galen was the fire in Rome in 192 CE that destroyed many of Galen's books ${ }^{16}$ and other possessions that he had placed in a storeroom in the vicinity of the Temple of Peace. When he wrote, the acquaintance already knew that Galen was not physically injured by the fire or emotionally distressed by the loss of his property (3). What the acquaintance, who was an admirer of Galen, wanted to know was this: How has Galen managed to keep his composure under such trying circumstances? As Galen puts it at the opening of the treatise, 'I received your letter in which you were encouraging me to make clear to you what training or which arguments or what teachings prepared me never to be distressed' (lypeisthai) (1). In addition, the acquaintance was eager to learn more of the details of Galen's loss: 'You said that you had learned that these things did, indeed, happen, but that you wanted to hear (about them) more precisely from me' (10).

In terms of the structure of the work, Galen cleverly answers the second question first, doing so in sections 1-37. In this part he dilates upon the great extent of his losses, using the rhetorical technique of amplification (auxēsis) to magnify the disaster that he and others have experienced. ${ }^{17}$ Although his acquaintance was 'amazed' (thaumasiōteron) by Galen (11), he had in fact underestimated Galen's achievement, for he did not realise the full extent of the loss that occurred that day (12b). Although the boyhood acquaintance did not personally experience all the terrible losses that took place, just learning about them would be sufficient to distress (lypēsei) him (16). That amplification leads in section 38 to a reformulation of the initial question:

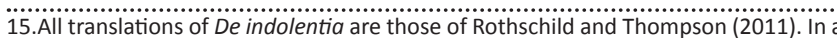
similar way, Plutarch wrote his On Tranquility of the Mind (De tranquillitate animi) in response to an epistolary request (465e). In Galen's case, such a request was by no means unique (see footnote 5 above on Boethus' requests). A similar request had been made before in regard to the emotions (De propriorium animi cuiuslibet affectuum dignotione et curatione 1.1) and requests from other acquaintances for Galen's thoughts on various topics would come later (De libris propriis Prologue Galen's thoughts on various topics would come later (De libris propriis Prologue Is Being Healthy a Part of Medicine or of Gymnastics?] 806).

16.On Galen's books and the links between his medical and non-medical corpus, see especially Nutton (2009).

17.On amplification as a rhetorical technique, see Fitzgerald (1997:285-288).
Perhaps then you will say that your desire is enjoined to want to know even more how, despite having lost such a great variety of (my) possessions - each of which alone, in and of itself, would have been most distressing (lypērotaton) for other human beings I was not troubled (aniathēn) like some others. Rather, I very easily endured what happened.

The leitmotif of the entire document is that Galen has endured without distress the loss of some of his prize possessions $(1,2,3,4,11,29,30,38,46,50 \mathrm{~b}, 70,72 \mathrm{~b})$. That Galen had not experienced distress is personal testimony, which is supported by the evidence of his radiant (raidron) countenance (3) and the unaffected regimen of his life (3). These are offered as physiognomic and medical proofs that he is alypos - not suffering any distress (Fitzgerald 2014:213-220).

In addition to his own testimony, Galen invokes his acquaintance's testimony about his composure when previous calamities occurred $(2,70)$. His current composure is corroborated by the testimony of a third party, who has reported Galen's robust emotional state to the acquaintance (3). Galen's emotional resilience is contrasted with the depression and distress of a certain Philides, who died as a consequence of losing his books, and also with the black garments and emaciated bodies of other people who had suffered losses (7). Thin and pale, the terms Galen uses to describe the latter (7), are physical symptoms of distress, indicating the loss of appetite that often accompanies emotional turmoil. These 'mourners' (penthousi) serve as rhetorical foils in Galen's comparison (synkrisis) of himself with those less emotionally stable.

This second part of his work (38-84) then sets forth the 'secret' of how to live a life free from distress and comprises three sections. In the first section (39-46) he gives three examples of philosophers from the distant past who had suffered losses without experiencing distress (39-45). They include Aristippus, the founder of the hedonist Cyrenaic school of philosophy (39-45), Crates and Diogenes (45), both Cynics. He later adds Zeno of Citium, the founder of Stoicism, as a fourth example (48). To the four exempla drawn from the past, he subsequently adds himself, regarding himself as 'a preeminent example' of megalopsychia [greatness of soul] (50b). At the same time, he is keen to qualify this boast by underscoring that, compared to the examples provided by these ancient worthies, his achievement is not really all that 'great'. As he puts it in 49 , 'No great (mega) thing was accomplished by me in despising the manifold loss of my possessions'. It is others, like Zeno, who are truly amazing (48).

As the preceding discussion of the text already suggests, Galen already begins in this first section of the second part of the work to answer the letter-writer's question, but the fuller, more formal reply is given in the second section (47-68). Here he indicates that the key to his freedom from distress is essentially five-fold: first, noble birth $(50 \mathrm{~b}, 60)$ and parental nurture (58-62), that is, by both nature and nurture he was favourably disposed to a life of virtue without distress (57); second, avoidance of the vice of insatiability (aplēstia:48), 
which not only renders insatiable people incapable of enjoying and being content with what possessions they do own, but also makes it impossible for them to lose any of their belongings, no matter how insignificant (43-44, 46); third, the proper understanding of possessions, namely that everything material is ultimately trivial (65); fourth, continuous training (askēsis:1, 54, 59, 74, 76) designed to make him ready for any of life's peristaseis, that is, hardships and adverse circumstances ${ }^{18}$ (41); and fifth, the good fortune of always having experienced only partial losses, not total ones and of never having been subjected to physical torture (71).

On the whole, what Galen says in this text is consistent with what he says about himself and lype in De propriorum animi cuiuslibet affectuum dignotione et curatione. For instance, in the latter treatise he makes the following statements:

I continued undaunted in the face of day by day occurrences throughout my life, just as I had seen my father do. No loss was enough to cause me grief (43). ${ }^{19}$

I am perfectly free from pain and grief (44).

If an ox or a horse or a slave died, this loss was not enough to cause me grief, because I remembered the counsel given me by my father when he advised me not to grieve over the loss of possessions (44).

Be sure that there is a single cause for all griefs. The Greeks sometimes call it insatiate desire and at other times covetousness (49).

If, then, we will exercise ourselves constantly and vigorously ..., we will be free from grief. But how will we exercise ourselves, if we have not first been won over to the belief that insatiate desire is correctly called the most villainous passion of the soul?

... If, then, being free from grief lies in this alone and this lies in our power, we can now be entirely free from grief by keeping the doctrines on greed and independence ready at hand and by practicing each day particular deeds in light of these doctrines (51-52).

In short, Galen's self-depiction and his 'prescription' for how to be free from distress are consistent in both works.

The third and final section contains Galen's clarifications, largely distinguishing his alypia ('freedom from distress') from Stoic and Cynic apatheia ('freedom from passion', 'the absence of emotion'), and from their attitude to potential hardships. If a man has many fields and loses one, but what remains is sufficient for him to meet his expenses, he can bear without distress the loss of that one field, since the loss is restricted to what is superfluous (41-46). On the other hand, it is reasonable (eilotōs) for people to become emotionally upset when they lose the only field they own and are now utterly without means (45). In short, a certain amount of lype is fully rational when financial losses involve necessities that one cannot live without. The same is true for other peristaseis. Galen is explicit that he is no superman. There are certain peristaseis in life such as seeing his homeland destroyed, his friend punished by a

18.On the Greek term peristasis and the Greco-Roman concept of peristaseis, see Fitzgerald (1988:33-46)

19.All translations of this work are those of Harkins (1963). tyrant (72a), or himself losing so many possessions that he would experience hunger, cold and thirst (78b) that, if they did occur, would indeed distress him. Similarly, he, unlike Cicero's virtuous man (De finibus [On Ends] 5.84-85), would not be happy in Phalaris' bull (71), and unlike the Stoic philosopher Musonius Rufus (73), he does not want Zeus to send any peristasis whatsoever into his life, but only those hardships that he can endure without experiencing distress (73). He prays for his hardships to be restricted to those that his nature, nurture, training and perspective will enable him to endure without distress. Similar caveats occur in De propriorum animi cuiuslibet affectuum dignotione et curatione, which indicate that, while Galen knows that he has been able to live remarkably free from distress thanks to his training and to the counsel he has received mostly from his father, he has also been fortunate in not having been 'tested' as severely as others. 'I do not know', he says, 'if I would grieve if I should lose all my possessions, for I have never yet experienced such a large loss' (43; see also 44).

Finally, in terms of De indolentia's content, some of the particulars in the text are, to my knowledge, new, for example Musonius' bold prayer for Zeus to send whatever peristasis he wants (73) is not previously attested for him. A very similar prayer, however, does appear in Epictetus (Dissertationes 1.6.37), the student of Musonius. Until now, scholars had generally assumed that the prayer originated with Epictetus, but De indolentia allows us to recognise that he derived it from his teacher. ${ }^{20}$ Similarly, the standard edition of Theophrastus (Fortenbaugh et al. 1992) can now be supplemented by the reference that Galen makes to Aristotle's successor in this text (17). But on the whole, Galen is giving stock arguments, common to the various philosophical schools and he is discussing issues commonly debated amongst the various schools. The traditional nature of much of his material can be illustrated by calling attention to a fragment from a lost play of Euripides that he twice quotes (52 and 77) in De indolentia and that he quotes a third time in his On the Doctrines of Hippocrates and Plato (De Placitis Hippocratis et Platonis 4.7.10), though the precise wording differs slightly each of the three times. It is fragment 964 (Nauck 1889) and consists of six lines. The quoted words are placed by Euripides in the mouth of Theseus, the legendary king of Athens. They express the sentiment that one can avoid or lessen the devastating impact of adversities by anticipating them beforehand. The quotation of these six lines is not unique to Galen. They are, for example, translated into Latin, quoted approvingly and interpreted by Cicero in his Tusculanae disputationes (Tusculan Disputations 3.29-30). In addition to Cicero, pseudo-Plutarch (Consolatio ad Apollonium [A Letter of Consolation to Apollonius] $112 \mathrm{~d}$ ) quotes the same six lines as does Galen, which indicates that we are dealing with material quoted from sources or taken from handbooks - not lines taken directly from Euripides' unknown play, and thus with widely known stock material that was congenial to numerous viewpoints.

\section{Galen and the New Testament}

Space does not permit a full comparison of Galen's perspective on grief with views found in the biblical tradition 20.Already noted by Boudon-Millot, Jouanna and Pietrobelli (2010:171). 
in general and early Christian literature in particular. The following three points are therefore intended as suggestive rather than comprehensive. Two points of similarity and one of contrast will be noted.

First, both the New Testament and Galen are fully aware that the loss of possessions, especially those with a significant financial or personal value, can cause grief and similar reactions. Galen depicts grief as the typical response of the people of Rome to the loss of their possessions in the fire, saying that 'one after another [of them] went out in black garments, thin and pale like mourners' (7). Similarly, in all three of the Synoptic Gospels the rich man who asks Jesus what he must do to obtain eternal life experiences grief at even the prospect of losing his great wealth as a result of selling all he owned and giving the proceeds to the poor (Mt 19:22; Mk 10:22; Lk 18:23). Paul, too, recognises that even voluntary giving can cause distress, and he urges the Corinthians to give cheerfully rather than under the duress of grief (2 Cor 9:7).

Second, both Galen and the biblical tradition understand that severe grief can cause death. Galen gives one example of death from grief in this treatise: 'When his books perished in the fire, Philides the grammarian - wasting away from discouragement and distress - actually died' (7). Elsewhere, Galen frequently notes death as the result of grief, which he explains medically as the consequence of an imbalance of mixtures in the body (Fitzgerald 2014:209, n. 34). The same connection between grief and actual or potential death also appears in biblical (Jnh 4:9, LXX) and Jewish literature (1 Macc 6:13; Sir 37:2) as well as in Jesus' words in Gethsemane (Mt 26:38; Mk 14:34). Paul, too, reflects awareness of the potentially fatal consequences of grief when he refers to worldly grief producing death (2 Cor 7:10).

Third, Galen is typical of antiquity in associating grief with insomnia - even referring in one of his works to 'the insomnia of grief' and occasionally prescribing theriac (a common Greco-Roman antidote that contained the opium poppy) to those suffering grief-induced sleeplessness (Fitzgerald 2014:212, n. 42). The Gospel of Luke, by contrast, explains that the disciples in Gethsemane were sleeping 'because of grief' (22:45). Furthermore, unlike Matthew and Mark, who depict Jesus as 'deeply grieved' (perilypos) in Gethsemane, Luke never attributes grief to Jesus, either here or anywhere else in his gospel. Consequently, the Lukan Jesus facing death is just as much without grief (alypos) as Galen claims to be after losing his prized possessions $(4,72 b)$. In redacting Mark, Luke has in effect shifted the emotion of grief away from Jesus and assigned it to the disciples (Wright 2014:268). This shift is in keeping with Luke's general depiction of Jesus as being much more emotionally calm during his final hours than he is in Matthew and Mark, but Luke is unique in the biblical tradition in connecting grief with sleep rather than sleeplessness.

\section{Conclusion}

In conclusion, the discovery of a lost text of Galen has justifiably caused excitement, precisely because of its relevance for many fields. Beyond that, in this letter-treatise we see Galen as an old man (61), reflecting on the loss of possessions accumulated over a lifetime and his reaction to that loss. He is proud to proclaim that a loss that was so potentially devastating did not cause him any distress at all, and he is particularly thankful to his father for the training and discipline that enabled him to remain cheerful under such an adverse circumstance. In his reply to his old fellow student, he shares the secret of his success, even as he prays (72b-73) that in the future he will not experience any hardship that would be more powerful than his soul could withstand (75).

As the final part of this article attempted to suggest, Galen is a potentially valuable author whose views can be profitably compared and contrasted with those of early Christian literature. If this article serves to prompt additional studies of Galen, both in his own right as an author and in comparison to the biblical tradition, it will have achieved one of the goals for which it was written.

\section{Acknowledgements Competing interests}

The author declares that he has no financial or personal relationships which may have inappropriately influenced him in writing this article.

\section{References}

Alexander, L., 1995, 'Paul and the Hellenistic schools: The evidence of Galen', in T. Engberg-Pedersen (ed.), Paul in his Hellenistic context, pp. 60-83, Fortress, Minneapolis, MN.

Alexander, L., 2008, 'The passions in Galen and the novels of Chariton and Xenophon', in J.T. Fitzgerald (ed.), Passions and moral progress in Greco-Roman thought, pp. 175-197, Routledge, New York.

Baillet, J. (ed.), 1920-1926, Inscriptions grecques et latines des tombeaux des rois ou syringes à Thebes, Institut français d'archéologie orientale, Le Caire.

Boudon [Boudon-Millot], V., 2002, ‘Galen's On My Own Books: New material from Meshed, Rida, Tibb. 5223', in V. Nutton (ed.), The unknown Galen, pp. 9-18, Institute of Classical Studies, London.

Boudon-Millot, V. (ed.), 2007, Introduction générale; Sur l'ordre de ses propres livres; Sur ses propres livres; Que l'excellent médecin est aussi philosophe, vol. 4, Les Belles Lettres, Paris.

Boudon-Millot, V., 2008a, 'The library of a Greek scholar in the Roman empire: New testimony from Galen's recently discovered Peri Alupias', in L. Cilliers (ed.) Asklepios: Studies on ancient medicine, pp. 7-18, Classical Association of South Africa, Bloemfontein.

Boudon-Millot, V., 2008b, 'Un traité perdu de Galien miraculeusement retrouvé, Le Sur l'inutilité de se chagriner: texte grec et traduction française', in V. BoudonMillot, A. Guardasole \& C. Magdelaine (eds.), La science médicale antique. Nouveaux regards. Études réunies en l'honneur de J. Jouanna, pp. 72-123, Beauchesne, Paris.

Boudon-Millot, V., Jouanna, J. \& Pietrobelli, A. (eds.), 2010, Galien: Ne pas se chagriner, Les Belles Lettres, Paris.

Bowersock, G.W., 1969, Greek sophists in the Roman empire, Clarendon, Oxford.

Bultmann, R., 1967, 'Iypē, lypeō, alypos, perilypos, syllupeomai', in G. Kittel (ed.), Theological dictionary of the New Testament, transl. G.W. Bromiley, vol. 4, pp. 313-324, Eerdmans, Grand Rapids, MI.

Cadbury, H.J., 1919, The style and literary method of Luke, Harvard University Press, Cambridge, MA.

Cadbury, H.J., 1926, 'Lexical notes on Luke-Acts: II. Recent arguments for medical language', Journal of Biblical Literature 45(1\&2), 190-209. http://dx.doi. org/10.2307/3260178

Edelstein, E.J. \& Edelstein, L., 1945, Asclepius: A collection and interpretation of the testimonies, Johns Hopkins, Baltimore, MD.

Fitzgerald, J.T., 1988, Cracks in an earthen vessel: An examination of the catalogues of hardships in the Corinthian correspondence, Scholars Press, Atlanta, GA.

Fitzgerald, J.T., 1997, 'The catalogue in ancient Greek literature', in S.E. Porter \& T.H. Olbricht (eds.), The rhetorical analysis of scripture: Essays from the 1995 London conference, pp. 275-293, Sheffield Academic Press, Sheffield. 
Fitzgerald, J.T., 2008, 'The passions and moral progress: An introduction', in J.T. Fitzgerald (ed.), Passions and moral progress in Greco-Roman thought, pp. 1-25, Fitzgerald (ed.), Passions
Routledge, New York.

Fitzgerald, J.T., 2014, 'Galen's De indolentia in the context of Greco-Roman medicine, moral philosophy, and physiognomy', in C.K. Rothschild \& T.W. Thompson (eds.), Galen's De indolentia: Essays on a newly discovered letter, pp. 203-220, Mohr Siebeck, Tübingen.

Fortenbaugh, W.W., Huby, P.M., Sharples, R.W. \& Gutas, D. (eds.), 1992, Theophrastus of Eresus: Sources for his life, writings, thought, and influence, Brill, Leiden.

Grant, R.M., 1983, 'Paul, Galen, and Origen', Journal of Theological Studies 34(2), 533-536. http://dx.doi.org/10.1093/jts/34.2.533

Hankinson, R.J. (ed.), 2008, The Cambridge companion to Galen, Cambridge University Press, Cambridge.

Harkins, P.W., 1963, 'Galen': On the passions and errors of the soul, Ohio State University Press, Columbus, $\mathrm{OH}$.

Hobart, W.K., 1882, The medical language of St. Luke, Hodges, Figgis \& Co., Dublin.

Janse van Rensburg, F., 2000, 'Dékor of Konteks? Die verdiskontering van sosiohistoriese gegewens in die interpretasie vir die prediking en pastoraat van ' Nuwe Testamentteks, geïllustreer aan die hand van die 1 Petrus-brief', Skrif en Kerk 21(3), 564-582.

Janse van Rensburg, F., 2004, 'The Old Testament in the salvific metaphors in 1 Peter', in J. Schlosser (ed.), The Catholic Epistles and the tradition, pp. 381-396, Peeters, Leuven.

Janse van Rensburg, F., 2005, 'Metaphors in the soteriology in 1 Peter: Identifying and interpreting the salvific imageries', in J.G. van der Watt (ed.), Salvation in the New Testament: Perspective on soteriology, pp. 409-435, Brill, Leiden.

Janse van Rensburg, F., 2006, 'A code of conduct for children of God who suffer unjustly: Identity, ethics and ethos in 1 Peter', in J.G. van der Watt (ed.), Identity, ethics and ethos in the New Testament, pp. 473-510, de Gruyter, Berlin.

Janse van Rensburg, F., 2009, 'No retaliation! An ethical analysis of the exhortation in 1 Peter 3:9 not to repay evil for evil', in J.T. Fitzgerald, F.J. van Rensburg \& H.F. van Rooy (eds.), Animosity, the Bible, and us, pp. 199-230, Society of Biblical Literature, Atlanta, GA.

Janse van Rensburg, F., 2011, 'The eschatology of 1 Peter: Hope and vindication for visiting and resident strangers', in J.G. van der Watt (ed.), Eschatology of the New Testament and some related documents, pp. 472-492, Mohr Siebeck, Tübingen.

Johnson, W.A., 2010, Readers and reading culture in the high Roman empire: A study of elite communities, Oxford University Press, Oxford.

Kleijwegt, M., 1991, Ancient youth: The ambiguity of youth and the absence of adolescence in Greco-Roman society, Gieben, Amsterdam.

Kudlien, F., 1981, 'Galen's religious belief', in V. Nutton (ed.), Galen: Problems and prospects, pp. 117-130, Wellcome Institute for the History of Medicine, London.

Malherbe, A.J., 1980, 'Medical imagery in the Pastoral Epistles', in W.E. March (ed.), Texts and testaments: Critical essays on the Bible and early church fathers: A volume in honor of Stuart Dickson Currie, pp. 19-35, Trinity University Press, San Antonio, TX.

Malherbe, A.J., 2014, Light from the Gentiles: Hellenistic philosophy and early Christianity, Collected essays, 1959-2012, Brill, Leiden.

Mansfeld, J., 2004, 'Galen, Papias, and others on teaching and being taught', in E.G. Chazon, D. Satran \& R.A. Clements (eds.), Things revealed: Studies in early Jewish and Christian literature in honor of Michael E. Stone, pp. 317-329, Brill, Leiden.
Marquardt, J., Von Müller, I. \& Heimrich, G. (eds.), 1884, Claudii Galeni Pergameni scripta minora, vol. 1, Teubner, Leipzig.

Mattock, J.N., 1972, 'A translation of the Arabic epitome of Galen's book Peri ēthōn', in S.M. Stern (ed.), Islamic philosophy and the classical tradition: Essays presented by his friends and pupils to Richard Walzer on his seventieth birthday, pp. 235-260, University of South Carolina Press, Columbia, SC.

Nasrallah, L.S., 2012, 'Grief in Corinth: The Roman city and Paul's Corinthian correspondence', in D.L. Balch \& A. Weissenrieder (eds.), Contested spaces: Houses and temples in Roman antiquity and the New Testament, pp. 109-139, Mohr Siebeck, Tübingen.

Nauck, A. (ed.), 1889, Tragicorum Graecorum fragmenta, 2nd edn., Teubner, Leipzig. Nutton, V., 1973, 'The chronology of Galen's early career', Classical Quarterly 23(1), 158-171. http://dx.doi.org/10.1017/S0009838800036600

Nutton, V., 2004, Ancient Medicine, 2nd edn., Routledge, London.

Nutton, V., 2009, 'Galen's library', in C. Gill, T. Whitmarsh \& J. Wilkins (eds.), Galen and the world of knowledge, pp. 19-34, Cambridge University Press, Cambridge.

Rothschild, C.K. \& Thompson, T.W., 2011, 'Galen: On the avoidance of grief', Early Christianity 2, 110-129. http://dx.doi.org/10.1628/186870311795386971

Schmidt, J.J.H., 1878, Synonymik der griechischen sprache, vol. 2, Teubner, Leipzig.

Singer, P.N., 1997, Galen: Selected works, Oxford University Press, Oxford.

Smallwood, E.M., 1976, The Jews under Roman rule, Brill, Leiden.

Spicq, C., 1994, Theological lexicon of the New Testament, transl. J.D. Ernest, vol. 2, Hendrickson, Peabody, MA.

Thompson, T.W., 2015, 'Galen, De indolentia, and early Christian literature', Bulletin for the Study of Religion 44(3), 20-25. http://dx.doi.org/10.1558/bsor.v44i3.27924

Vallance, J.T., 1990, The lost theory of Asclepiades of Bithynia, Clarendon, Oxford.

Van der Horst, P.W.R., 2007, 'Unnik, W.C. van', in D.K. McKim (ed.), Dictionary of Major Biblical Interpreters, pp. 1002-1005, InterVarsity Press, Downers Grove, IL.

Van Unnik, W.C., 1971, 'Words come to life: The work for the "Corpus Hellenisticum Novi Testamenti"', Novum Testamentum 13(3), 199-216. http://dx.doi. org/10.1163/156853671X00035

Von Staden, H., 1997, 'Erasistratus', in D.J. Zeyl (ed.), Encyclopedia of classical philosophy, pp. 219-220, Greenwood, Westport, CT.

Von Staden, H., 2004, 'Galen's Alexandria', in W.V. Harris \& G. Ruffini (eds.), Ancient Alexandria between Egypt and Greece, pp. 179-215, Brill, Leiden.

Walsh, J., 1927, 'Galen visits the Dead Sea and the copper mines of Cyprus (166 A.D.)', Bulletin of the Geographical Society of Philadelphia 25, 93-110.

Welborn, L.L., 2011, 'Paul and pain: Paul's emotional therapy in 2 Corinthians $1.1-2.13 ; 7.5-16$ in the context of ancient psychagogic literature', New Testament Studies 57, 547-570. http://dx.doi.org/10.1017/S0028688511000142

White, L.M., 2014, 'The pathology and cure of grief (lypē): Galen's De indolentia in context', in C.K. Rothschild \& T.W. Thompson (eds.), Galen's 'De indolentia': Essays on a newly discovered letter, pp. 221-249, Mohr Siebeck, Tübingen.

Wilken, R.L., 1984, The Christians as the Romans saw them, Yale University Press, New Haven, CT.

Wright, R.A., 2014, 'Possessions, distress, and the problem of emotions: De indolentia and the Gospel of Luke in juxtaposition', in C.K. Rothschild \& T.W. Thompson Mohr Siebeck, Tübingen. 